\title{
THE APPLICATION OF PLANNED BEHAVIOR THEORY ON MILLENNIAL GENERATION BEHAVIOR IN PURCHASING ORGANIC VEGETABLES
}

\author{
Yusuf Ramadhan*)1, Mukhamad Najib"), and Ma'mun Sarma*) \\ *) Department of Management, Faculty of Economics and Management, IPB University \\ Jl. Agatis, Campus of IPB Darmaga Bogor 16680, Indonesia
}

\begin{abstract}
Organic vegetables are vegetables that are cultivated without any synthetic chemicals. Organic vegetables production volume is increasing every year. There are expectations of increasing the annual production of organic food in order to provide safe and healthy food. Vegetables are one of the basic needs that are consumed daily in Indonesia. This research aimed to analyze the buying behavior of organic vegetables of millennials in Bandung city. This research tried to expand the Theory of Planned Behavior (TPB) by adding one variable, namely health consciousness, in the research framework. The methods used in this research were Confirmatory Factor Analysis (CFA) and Structural Equation Modeling (SEM) with the AMOS approach. The number of samples used were was 208 respondents. Millennial Generation respondents consisted of people aged 21 to 40 years old whoi were selected with a sampling technique of quota sampling. Data collection was conducted by distributing online questionnaires using Google Forms via WhatsApp and Instagram. The results showed that the purchase intention variable had the most dominant influence toward on buying behavior. While health consciousness, which was an addition of the Theory of Planned Behavior modification, had the most dominant effect toward perceived behavioral control.
\end{abstract}

Keywords: theory of planned behavior, health consciousness, organic vegetables, millennial generation, structural equation modeling (SEM)

\begin{abstract}
Abstrak: Sayur organik adalah sayuran yang dibudidayakan secara alami dan tanpa bantuan bahan kimia sintetis. Setiap tahun sayuran organik mengalami peningkatan jumlah produksi, produksi sayuran organik diharapkan akan terus meningkat setiap tahunnya untuk mampu menyediakan bahan pangan yang aman dan sehat. Sayuran merupakan salah satu kebutuhan pokok yang setiap harinya dikonsumsi oleh masyarakat Indonesia. Tujuan penelitian ini adalah untuk memahami perilaku pembelian sayur organik pada generasi milenial di Kota Bandung. Penelitian ini juga mencoba untuk memperluas Theory of Planned Behavior (TPB) dengan menambahkan satu variabel tambahan yaitu kesadaran pada kesehatan (health consciousness) dalam kerangka penilitian. Metode yang digunakan dalam penelitian ini adalah Confirmatory Factor Analysis (CFA) dan Structural Equation Modeling (SEM) dengan pendekatan AMOS, jumlah sampel yang digunakan sebanyak 208 responden. Responden Generasi Milenial terdiri dari rentang usia 20-40 tahun dengan teknik pengambilan sampel menggunakan kuota sampling. Pengumpulan data dilakukan dengan cara meyebarkan kuesioner secara online menggunakan Google Form yang disebarkan melalui WhatsApp dan Instagram. Hasil penelitian menunjukkan bahwa variabel purchase intention memiliki pengaruh yang paling dominan terhadap purchase behavior. Sedangkan health consciousness yang merupakan penambahan variabel dari modifikasi Theory of Planned Behavior memiliki pengaruh paling dominan terhadap perceived behavioral control.
\end{abstract}

Kata kunci: theory of planned behavior, health consciousness, sayur organik, generasi milenial, structural equation modeling (SEM)

${ }^{1}$ Corresponding author:

Email: yusuframdhn@gmail.com 


\section{INTRODUCTION}

Organic agriculture is an agriculture that relies on natural ingredients without synthetic chemicals. Basically, organic farming practices limit the negative impact caused by chemical farming or often referred to as conventional agriculture. As an agrarian country, Indonesia has excellent natural conditions. Thus, it can yield agricultural products of the highest quality.

Organic vegetables are the second most favorite organic product after organic rice (Muljaningsih, 2011). Most people are not yet familiar with organic products, and differing perceptions led to various questions, ranging from what is organic products, it is expensive, it's difficult to get, how to cultivate organic products, and other perceptions of other organic products.

Based on National Standardization Agency (Badan Standarisasi Nasional [BSN], 2016), organic is a term which states that a product has been produced in accordance with the standards of the organic farming system and it is certified by an accredited Organic Certification Agency. Many people are currently unaware of the importance of healthy living. In Indonesia, one of the efforts to start living healthy is to introduce organic food that was first coined as a term in Indonesia in 1997.

Worthington (2001) stated that organic vegetables has have higher vitamin and mineral average content than non-organic vegetables. In general, organic vegetables are recommended as good for health when consumed because it has health benefits in the long run (Islam, 2014). The increase in organic food sales is triggered by customer awareness and healthy lifestyles with the slogan "back to nature" (Hossain, 2007).

According to the West Java BPS (2019), the average expenditure on vegetable consumption in 2018 in West Java was Rp35,336 per capita in a month. The statistical data for organic vegetables demand in Bandung city has not been yet available because it has not been well documented by the relevant government agencies. According to (BPS, 2018) Bandung city has a population of millennials of around 889,755 people, whose age ranges from 21 to 40 years old. Martin \& Tulgan (2002) in Putra (2016) stated that millenials are those who were born in from 1981 to 1999.
The current and the future Indonesian market is dominated by the millennial generation. In 2020, millennials will be the largest percentage of all population and they will continue to dominate in 2035 (Rizkia, 2019). Alvara Research Center has conducted face to face survey on the millennial generation behavior since 2016, including around 1,200 respondents in Indonesia.

The results categorized nine millennial generation behaviors, which are: 1) Internet addiction. 2) Frequent change of heart. Millennial loyalty level towards the brand is lower. 3) Having less money. Millennial does not mean that they do not have more money to do cashless/non-cash transactions. 4) Work fast, work smart. 5) They can be anything. Millennial usually multitasks, doing two to three jobs at once. 6) Vacation anytime, anywhere. 7) Apathetic to politics. Millennial considers politics is a matter for millennial parents and ignore various political processes. 8) The tendency to share. Millennial has the generosity to share and social activities, as well as sharing both offline and online content. 9) Disregard for ownership. Access is more important than ownership.

Referring to the nine behaviors of millennials, there is a relevant behavior and it is interesting to study. Millenials easily change preferences or has low loyalty towards the brand. Vegetables are classified into three types, which is are organic, inorganic, and hydroponic. All three have differences in terms of price, planting methods, handling, level of health after consumption, and other differences.

The aim of this research aimed was to learn millennial's buying behaviour in relationconcerning to the theory of planned behavior from Ajzen (1991). TPB is used to predict an individual's intention in particular time and place. This theory are is meant to explain behaviour where someone is able tocan exert some control of themself (Ajzen, 1991). Health consciousness was added to identify interest in health as the main motivation to buy organic produce. Other than that, health consciousness could be used to predict attitude, intention, dan purchase of organic food (Michaelidou \& Hassan, 2008). The hypothesis in Table 1 was formulated into Figure 1 which shows the conceptual research framework. 


\section{METHODS}

Data used in this research were primary and secondary data. The primary data used in this research were obtained based on questionnaire' which were distributed to Millennial Generation respondents who lives in Bandung city. Secondary data used in this research were obtained from (AOI, BPS, SPOI), books, journals, and the internet.

The respondents involved in this research were 208 people in total. Determination of the number of respondents was based on the recommendations from Hair et al. (2010), the required number of samples had to at least 5-10 times the number of indicators. The indicators in this research were 26 indicators. Thus, the number of respondents needed was $8 \times 26=208$ respondents.

The technique of sample collection was quota sampling. The criteria used for screening respondents were: 1) consumers who had bought organic vegetables at least once in the last three months, 2) millennial generation customers who were born in the range 1980-1999, and 3) one respondent per family only, so there are no multiple data for the same family.

Measurement of indicators were was done using a Likert scale with the value of 1 to 5 . According to Oei (2010), Likert scale measure the level of agreement or disagreement of respondents to a series of statements that used to indicate an object. The Likert scale provisions were: 1) Strongly Disagree, 2) Disagree, 3) Fairly Agree, 4) Agree, and 5) Strongly Agree.

The Aanalysis used in this research were CFA (Confirmatory Factor Analysis) and SEM (Structural Equation Modeling). CFA is useful in testing how good variables measured (indicators) at describing or representing a number ofseveral factors. In CFA, factors can also be called constructs.

SEM is a multivariate statistical analysis technique that allows researchers to examine the direct and indirect effects between complex variables, both recursive and non-recursive, to obtain a comprehensive picture of a model. The hypothesis in Table 1 was formulated into Figure 1 which shows the conceptual research framework.

\section{RESULTS}

The Rresult of the research were was concluded by the majority of answers in the questionnaires. Most respondents were women, which made up $65.4 \%$ of all respondents. The majority of respondents were 25 years of age (32.2\% of respondents). Considering the upper limit of the age range was still quite young, it reflected on how the most common marital status of respondents was single/unmarried ( $65.4 \%$ of respondents). As a country with a majority Muslim population, the Muslims respondents made up $98.5 \%$ of the respondents. The majority of respondents were Sundanese which made up $69.3 \%$ of respondents. Most respondents had completed Bachelor level of education (59.6\% of respondents). Private employees made up $44.7 \%$ of the respondents, and a monthly income of Rp2,500,000 - Rp5,000,000 were most common ( $48.1 \%$ of respondents).

Most millennials in city of Bandung are found to be spending more than Rp. 100.000 to buy organic produce per month $23.6 \%$, while some spent Rp. $30.000-40.000$ for organic produce per month $10.1 \%$. This indicated that Millennials in Bandung like organic vegetables and care more about their health.

Millennials are particular in many ways, including deciding what they are interested in as a hobby, and the questionnaire indicated that millennials in Bandung commonly watch movies as their hobby $(44.7 \%$ of all respondents).

\section{Analysis of Confirmatory Factor Analysis (CFA)}

This research was conducted by using the Confirmatory Factor Analysis (CFA) method with the assessment of AMOS program. There are sSeveral stages of testing that must be conducted. The testing included assessing the suitability of the measurement model and the compatibility of the whole model.

In the initial model of goodness of fit test, the chi-square, probability, GFI, AGFI, TLI, CMIN/DF and RMSEA values are found to be poor fit because they didn't fulfill the existing criteria. Thus, they couldn't be used ion the next stage. Furthermore, the modification of the research model was needed. There were several excluded indicators including (ATT2, ATT4, SN1, SN4, PBC1, PBC4, PBC5, PBC6, PI1, PI5 and PB1). After the modification, the goodness of fit was better. The results of testing the goodness of fit after modification in Figure 2. 
Table 1. Research hypothesis

\begin{tabular}{clc}
\hline Hypothesis & Description & Path \\
\hline H1 & Health consciousness (HC) affects attitude (ATT) & $\mathrm{HC} \rightarrow \mathrm{ATT}$ \\
H2 & Health consciousness (HC) affects subjective norm (SN) & $\mathrm{HC} \rightarrow \mathrm{SN}$ \\
H3 & Health consciousness (HC) affects perceived behavioral control (PBC) & $\mathrm{HC} \rightarrow \mathrm{PBC}$ \\
H4 & Health consciousness (HC) affects purchase intention (PI) & $\mathrm{HC} \rightarrow$ PI \\
H5 & Subjective norm (SN) affects attitude (ATT) & $\mathrm{SN} \rightarrow \mathrm{ATT}$ \\
H6 & Subjective norm (SN) affects perceived behavioral control (PBC) & $\mathrm{SN} \rightarrow$ PBC \\
H7 & Subjective norm (SN) affects purchase intention (PI) & $\mathrm{SN} \rightarrow$ PI \\
H8 & Attitude (ATT) affects purchase intention (PI) & $\mathrm{ATT} \rightarrow$ PI \\
H9 & Perceived behavioral control (PBC) affects purchase intention (PI) & $\mathrm{PBC} \rightarrow$ PI \\
H10 & Perceived behavioral control (PBC) affects purchase behavior (PB) & $\mathrm{PBC} \rightarrow \mathrm{PB}$ \\
H11 & Purchase intention (PI) affects purchase behavior (PB) & $\mathrm{PI} \rightarrow \mathrm{PB}$
\end{tabular}

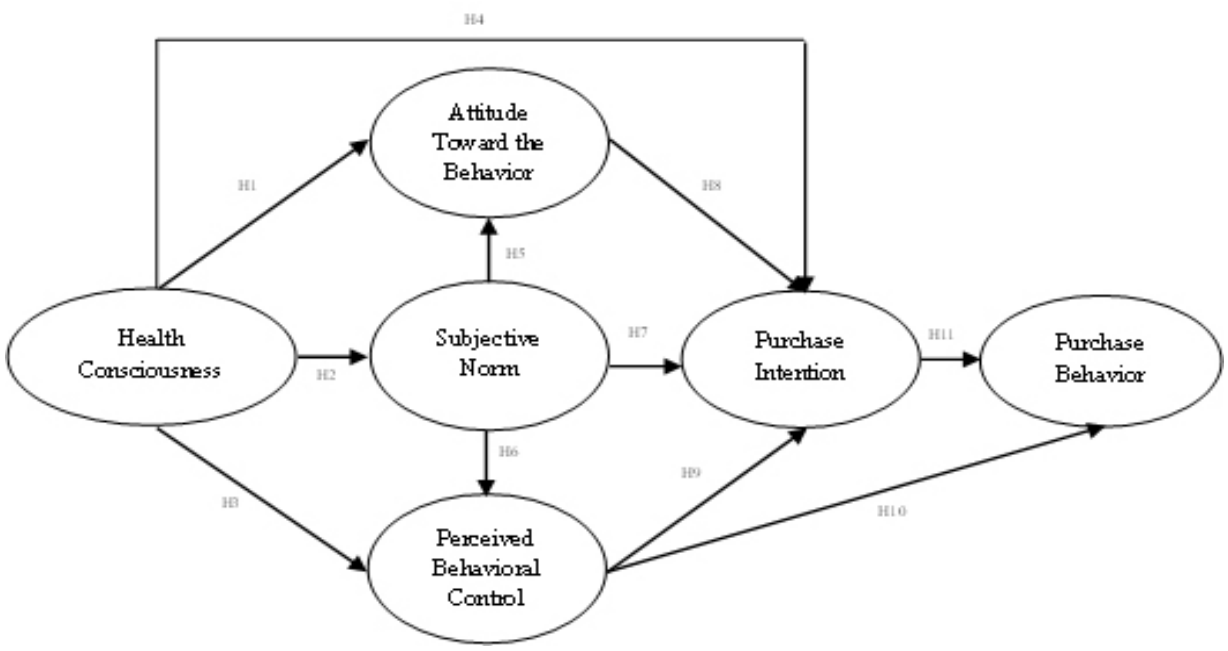

Figure 1. Research framework

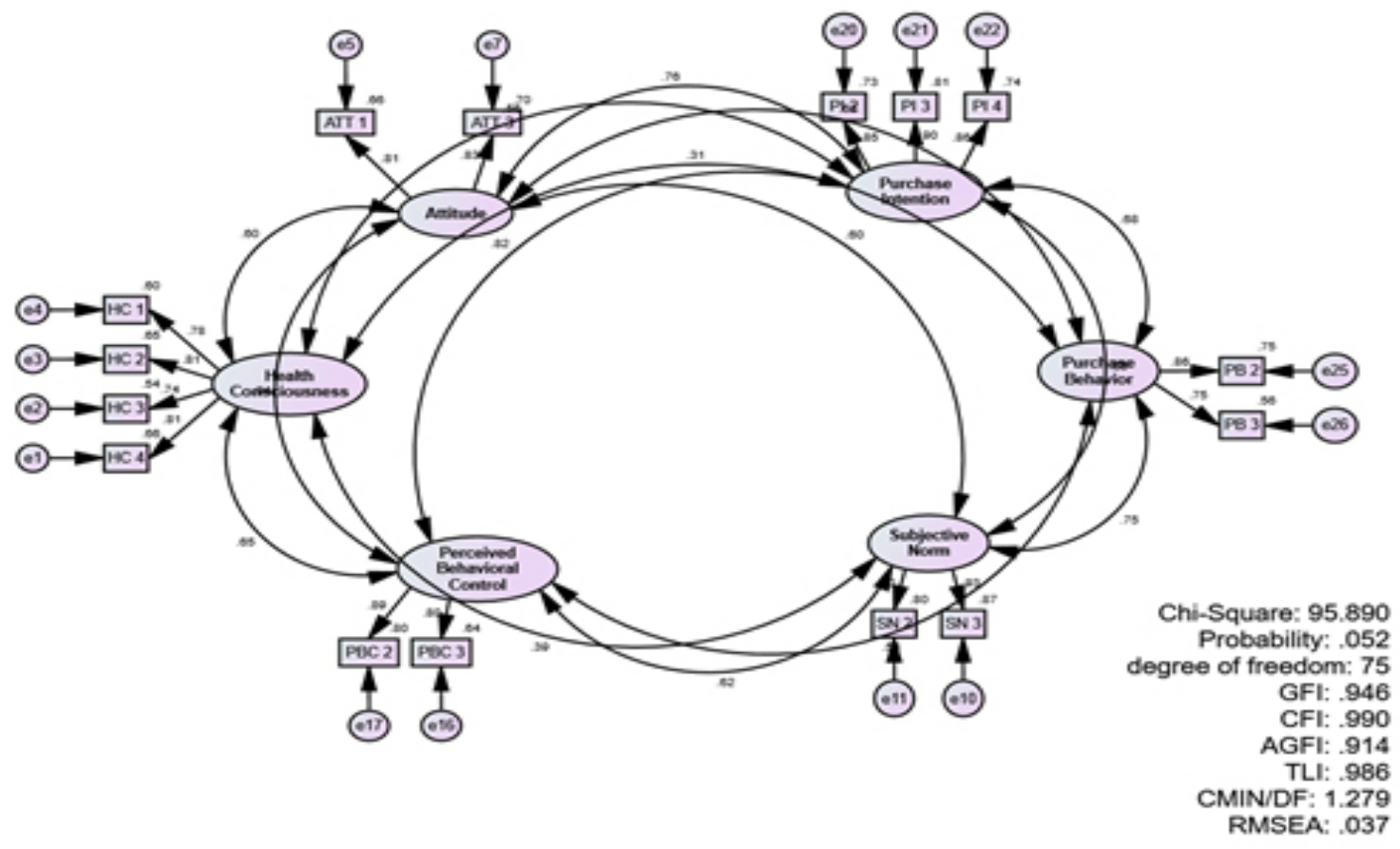

Figure 2. Final Model Confirmatory Factor Analysis (CFA) 
Furthermore, a feasibility test of the final CFA model in Figure 2 is conducted. From the path diagram in Figure 2, it's apparent that the CFA Model has a good fit because the probability value of Chi-Square $\geq 0.05$ is equal to 0.052 . Likewise, the values of Degree of Freedom, GFI, CFI, AGFI, TLI, CMIN / DF and RMSEA have met the recommended values (Table 2).

\section{Analysis of Structural Equation Model (SEM)}

As shown in diagram, the full path of SEM model didn't fit because Chi-square value was 184,232 with a probability of $(\mathrm{P}) \leq 0.05$ that was equal to 0,000 . Thus, it was necessary to modify the model to decrease the value of Chi-Square to make the model fit, by making the covariance between the indicators that had the Modification Indices (M.I) as the largest value.
On Modification Indices, some covariance were selected, which were e4 and e3; e4 and e16; e5 and e17; e5 and e10; e5 and e16; e7 and e17; e7 and e16; e7 and e22; e10 and e22; e10 and e25; e11 and e25; e11 and e26; e11 and e16; e16 and e26 which were used to to obtain the Full Model SEM diagram in Figure 3.Table 3 is shows the results from research model modification. Chi-Square, Probability, AGFI, CMIN/ DF and RMSEA values that were initially indicated as bad/ poor (Bad Fit and Marginal) were indicated as Good (Good Fit) after modification.

\section{Construct Reliability and Variance Extracted}

Cut off value of construct reliability test is $>0.70$ in order to be accepted. However, if the nature of research is explanatory, then the value under 0.7 is still accepted.

Table 2. Test Results of Final Model Confirmatory Factor Analysis (CFA)

\begin{tabular}{lccc}
\hline \multicolumn{1}{c}{ Goodness of Fit Index } & Cut off Value & Results & Criteria \\
\hline$\chi 2$ - Chi Square & Expected to be small & 95.890 & Good Fit \\
Significance Probability & $\geq 0.05$ & 0.052 & Good Fit \\
Degree of Freedom & $>0$ & 75 & Over Identified \\
GFI & $\geq 0.90$ & 0.946 & Good Fit \\
CFI & $\geq 0.90$ & 0.990 & Good Fit \\
AGFI & $\geq 0.90$ & 0.914 & Good Fit \\
TLI & $\geq 0.90$ & 0.986 & Good Fit \\
CMIN/ DF & $\leq 2.0$ & 1.279 & Good Fit \\
RMSEA & $\leq 0.08$ & 0.037 & Good Fit \\
\hline
\end{tabular}

Table 3. Test Results of Full Model Structural Equation Modeling (SEM)

\begin{tabular}{lccc}
\hline \multicolumn{1}{c}{ Goodness of Fit Index } & Cut off Value & Results & Criteria \\
\hline$\chi 2$ - Chi Square & Expected to be small & 72.921 & Good Fit \\
Significance Probability & $\geq 0.05$ & 0.234 & Good Fit \\
Degree of Freedom & $>0$ & 65 & Over Identified \\
GFI & $\geq 0.90$ & 0.956 & Good Fit \\
CFI & $\geq 0.90$ & 0.996 & Good Fit \\
AGFI & $\geq 0.90$ & 0.920 & Good Fit \\
TLI & $\geq 0.90$ & 0.994 & Good Fit \\
CMIN/ DF & $\leq 2.0$ & 1.122 & Good Fit \\
RMSEA & $\leq 0.08$ & 0.024 & Good Fit \\
\hline
\end{tabular}




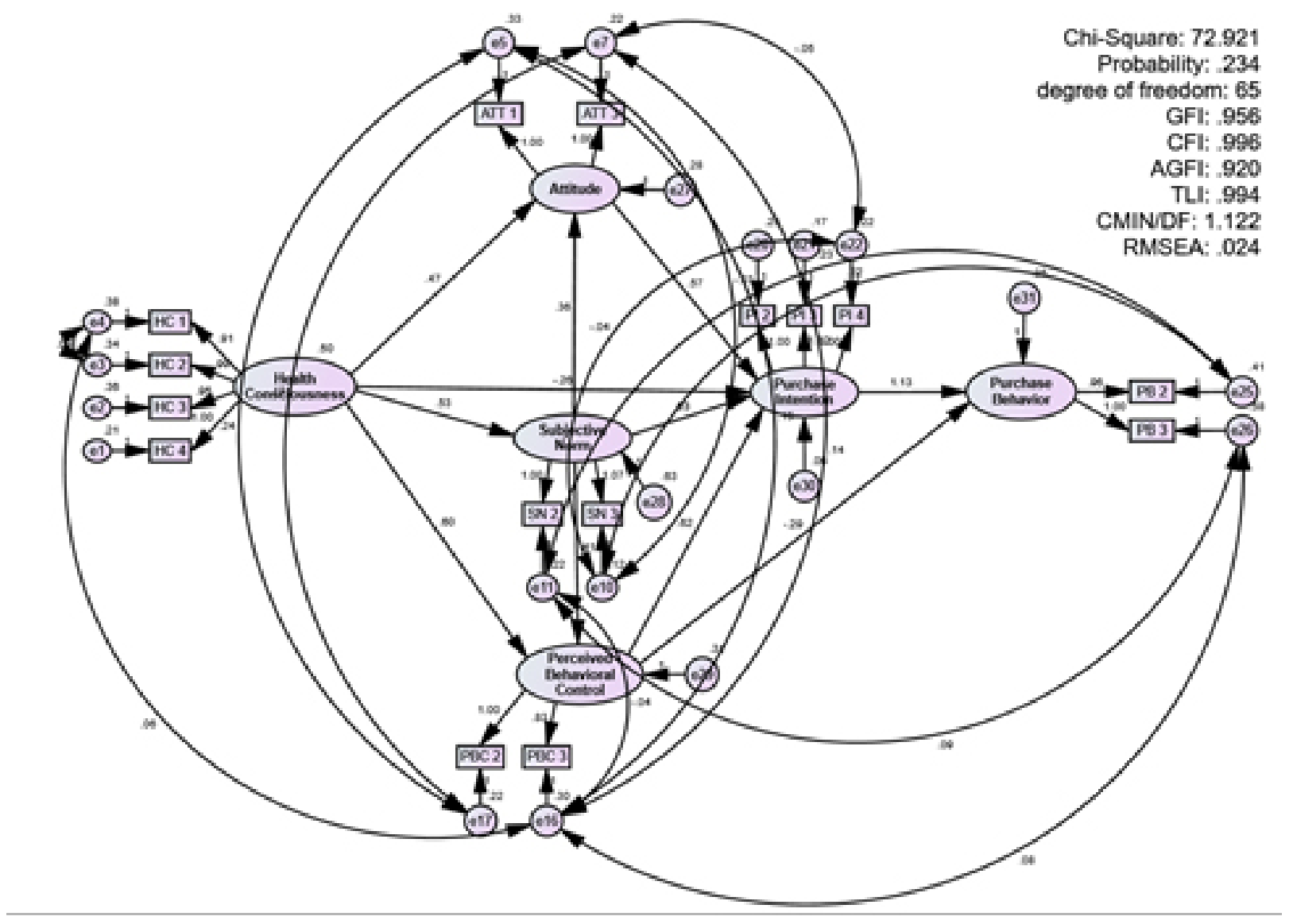

Figure 3. Full Model Structural Equation Modeling (SEM)

The recommended cut off value of variance extracted test is $>0.50$. Extracted variance value (VE) of $>0.50$ indicates that the amount of variance of the indicators extracted by the latent construct is bigger than the error variance. The results of construct reliability and variance extracted respecsification models can be seen in Table 4.

\section{Hypothesis Test}

As shown in Table 5, the accepted results of hypothesis test had a probability value of less than 0.05 and an absolute critical value of more than 1,967. Out of 11 hypotheses, there were 8 hypotheses that were received and gave significant effect, namely H1, H2, H3, H5, $\mathrm{H} 6, \mathrm{H} 8, \mathrm{H} 9$ and $\mathrm{H} 11$; while $\mathrm{H} 4, \mathrm{H} 7$, and $\mathrm{H} 10$ were rejected and had no significant effect. The test criterion is to reject H0 if the t-value or Critical Ratio (C.R.). $\geq$ 1,967 or value $\mathrm{p} \leq 0.05$.

\section{Health Consciousness affects Attitude}

The results of the t-value or C.R. were 5,575 $\geq 1,967$ or there was a $* * *$ sign on the $\mathrm{P}$ value. Thus, $\mathrm{H} 1$ was accepted. Michaelidou \& Hassan (2008) dan Hsu,
Chang dan Lin (2016) stated that health consciousness had a significant effect on attitude, which was the most important in shaping motivation to buy organic produce. It can be concluded that health consciousness has a positive and significant effect toward on attitude. These results explain that consumers who have an awareness of their health will have a positive attitude towards buying behavior of organic vegetables and they believe that organic vegetables have a better nutritional content than conventional vegetables.

\section{Health Consciousness affects Subjective Norm}

The results of the t-value or C.R. were $5.620 \geq 1.967$ or there was sign on the $\mathrm{P}$ value. Thus, $\mathrm{H} 2$ was accepted. Ajzen (2005) said subjective norm is an individual's perception to of the expectations of influential people in their life (significant others) regarding something they do or did not do. It can be concluded that health consciousness has a positive and significant effect toward on subjective norms. These results explain health consciousness can affect subjective norms in buying behavior of organic vegetables. In this case, consumers have confidence that organic vegetables are healthier and better for consumption in the long run. 
Table 4. Construct reliability and variance extracted model

\begin{tabular}{|c|c|c|c|c|c|c|}
\hline Variable & Indicator & $\begin{array}{l}\text { Standard } \\
\text { Loading }\end{array}$ & $\begin{array}{l}\text { Standard } \\
\text { Loading }^{2} \\
\end{array}$ & $\begin{array}{l}\text { Measurement Error } \\
(1-\text { Standard Loading })\end{array}$ & $\begin{array}{l}\text { Construct } \\
\text { Reliability }\end{array}$ & $\begin{array}{l}\text { Variance } \\
\text { Extracted }\end{array}$ \\
\hline \multirow{6}{*}{$\begin{array}{c}\text { Health } \\
\text { Consciousness }\end{array}$} & $\mathrm{HC} 1$ & 0.722 & 0.521 & 0.478 & \multirow{6}{*}{0.853} & \multirow{6}{*}{0.594} \\
\hline & $\mathrm{HC} 2$ & 0.770 & 0.592 & 0.407 & & \\
\hline & $\mathrm{HC} 3$ & 0.744 & 0.553 & 0.446 & & \\
\hline & $\mathrm{HC} 4$ & 0.842 & 0.708 & 0.291 & & \\
\hline & $\sum$ & 3.078 & 2.374 & 1.622 & & \\
\hline & $\sum^{2}$ & 9.474 & & & & \\
\hline \multirow[t]{4}{*}{ Attitude } & ATT1 & 0.798 & 0.636 & 0.363 & \multirow{4}{*}{0.810} & \multirow{4}{*}{0.681} \\
\hline & ATT3 & 0.852 & 0.725 & 0.274 & & \\
\hline & $\Sigma$ & 1.65 & 1.361 & 0.637 & & \\
\hline & $\Sigma^{2}$ & 2.722 & & & & \\
\hline \multirow{4}{*}{$\begin{array}{l}\text { Subjective } \\
\text { Norm }\end{array}$} & SN2 & 0.882 & 0.777 & 0.222 & \multirow{4}{*}{0.908} & \multirow{4}{*}{0.831} \\
\hline & SN3 & 0.941 & 0.885 & 0.114 & & \\
\hline & $\Sigma$ & 1.823 & 1.662 & 0.336 & & \\
\hline & $\Sigma^{2}$ & 3.323 & & & & \\
\hline Perceived & $\mathrm{PBC} 2$ & 0.879 & 0.772 & 0.227 & \multirow{4}{*}{0.826} & \multirow{4}{*}{0.704} \\
\hline \multirow{3}{*}{$\begin{array}{c}\text { Behavioral } \\
\text { Control }\end{array}$} & $\mathrm{PBC} 3$ & 0.798 & 0.636 & 0.363 & & \\
\hline & $\sum$ & 1.677 & 1.408 & 0.59 & & \\
\hline & $\Sigma^{2}$ & 2.812 & & & & \\
\hline \multirow{5}{*}{$\begin{array}{l}\text { Purchase } \\
\text { Intention }\end{array}$} & PI2 & 0.849 & 0.720 & 0.279 & \multirow{5}{*}{0.900} & \multirow{5}{*}{0.751} \\
\hline & PI3 & 0.890 & 0.792 & 0.207 & & \\
\hline & PI4 & 0.861 & 0.741 & 0.258 & & \\
\hline & $\sum$ & 2.6 & 2.251 & 0.744 & & \\
\hline & $\Sigma^{2}$ & 6.76 & & & & \\
\hline \multirow{4}{*}{$\begin{array}{l}\text { Purchase } \\
\text { Behavior }\end{array}$} & PB2 & 0.808 & 0.652 & 0.347 & \multirow{4}{*}{0.765} & \multirow{4}{*}{0.619} \\
\hline & PB3 & 0.766 & 0.586 & 0.413 & & \\
\hline & $\Sigma$ & 1.574 & 1.238 & 0.76 & & \\
\hline & $\Sigma^{2}$ & 2.477 & & & & \\
\hline
\end{tabular}

Table 5. Research hypothesis

\begin{tabular}{lcccc}
\hline \multicolumn{1}{c}{ Hypotheses } & Estimate & C.R. & P & Result \\
\hline Attitude $\leftarrow$ Health Consciousness & .467 & 5.475 & $* * *$ & Accepted \\
Subjective Norm $\leftarrow$ Health Consciousness & .533 & 5.620 & $* * *$ & Accepted \\
Perceived Behavioral Control $\leftarrow$ Health Consciousness & .600 & 6.669 & $* * *$ & Accepted \\
Purchase Intention $\leftarrow$ Health Consciousness & -.260 & -2.328 & .020 & Not Accepted \\
Attitude $\leftarrow$ Subjective Norm & .355 & 5.462 & $* * *$ & Accepted \\
Perceived Behavioral Control $\leftarrow$ Subjective Norm & .414 & 6.019 & $* * *$ & Accepted \\
Purchase Intention $\leftarrow$ Subjective Norm & .034 & .418 & .676 & Not Accepted \\
Purchase Intention $\leftarrow$ Attitude & .571 & 5.736 & $* * *$ & Accepted \\
Purchase Intention $\leftarrow$ Perceived Behavioral Control & .620 & 6.208 & $* * *$ & Accepted \\
Purchase Behavior $\leftarrow$ Perceived Behavioral Control & -.290 & -2.015 & .044 & Not Accepted \\
Purchase Behavior $\leftarrow$ Purchase Intention & 1.126 & 6.338 & $* * *$ & Accepted \\
\hline
\end{tabular}


Health Consciousness affects Perceived Behavioral Control

The results of the t-value or C.R. was $6,669 \geq 1,967$ or there was a ${ }^{* * *}$ sign on the $\mathrm{P}$ value. Therefore, $\mathrm{H} 3$ was accepted. It can be concluded that health consciousness has a positive and significant effect on perceived behavioral control. These results explain that health consciousness can affect perceived behavioral control, the concept of perceived behavioral control proposed by Ajzen is influenced by the research of (Bandura, 1977) on self-efficacy by adding the importance of individual control to the resources needed to realize certain behaviors (Ajzen, 2002).

\section{Subjective Norm affects Attitude}

The results of the t-value or C.R. was $5.462 \geq 1.967$ or there was a ${ }^{* * *}$ sign on the $\mathrm{P}$ value. Therefore, $\mathrm{H} 5$ was accepted. Paul et al. (2016) stated that subjective norm significantly affects attitude.

Thus, it can be concluded that subjective norm has a positive and significant effect on attitude. These results explain that family, friends and people who are considered important to individual/ subjective norms can affect attitudes in buying behaviour of organic vegetables.

Subjective Norm affects Perceived Behavioral Control The results of the t-value or C.R. were $6,019 \geq 1,967$ or there was a $* * *$ sign on the $\mathrm{P}$ value. Paul et al. (2016) stated that subjective norm significantly affect perceived behavioral control. Thus, H6 was accepted. It can be concluded that the subjective norm has a positive and significant effect toward on perceived behavioral control. These results explain that family, friends and people who are considered important to individual, or subjective norm, can affect attitudes in buying behaviour of organic vegetables.

\section{Attitude affects Purchase Intention}

The results of the t-value or C.R. were $5.736 \geq 1.967$ or there was a $* * *$ sign on the $\mathrm{P}$ value. Chaudhary \& Bisai (2018) and Paul et al. (2016) stated that attitude significantly affect purchase intention. Thus, $\mathrm{H} 8$ was accepted. It can be concluded that attitude has a positive and significant effect toward on purchase intention. These results explain that attitude can affect purchase intention on organic vegetables. Purchase intention is the behavioral tendency of interested consumers in taking actions related to purchasing through various stages and levels of possibility, to the ability to buy certain products, services or brands.

Perceived Behavioral Control influences Purchase Intention

The results of the t-value or C.R. were $6,208 \geq 1,967$ or there was a ${ }^{* * *}$ sign on the $\mathrm{P}$ value. de Leeuw et al. (2015), Paul et al. (2016) and Shaharudin et al. (2010) stated that perceived behavioural control significantly affect purchase intention. Thus, H9 was accepted. It can be concluded that perceived behavioral control has a positive and significant effect on purchase intention. These results explain that perceived behavioral control can affect purchase intention in organic vegetables, perceived behavioral control describes feelings of selfefficacy or the ability of individual self in a behavior.

\section{Purchase Intention affects Purchase Behavior}

The results of the $t$-value or C.R. were $6.338 \geq 1.967$ or there was a $* * *$ sign on the P value. Chaudhary (2018), Chaudhary \& Bisai (2018) and Paul et al. (2016) stated that purchase intention significantly affect purchase intention purchase behaviour. Thus, H11 was accepted. It can be concluded that purchase intention has a positive and significant effect toward on purchase behavior. These results explain that purchase intention can affect the purchase behavior of organic vegetables.

Health consciousness only had an indirect effect on purchase behaviour, with the a value of 0.377 . Based on the results in Table 6, it can be seen Figure 4 the direct effect of health consciousness toward perceived behavioral control has the greatest direct effect $(0.488)$ compared to the direct effect of attitude (0.437), subjective norm (0.429) and purchase intention $(-0.231)$. The direct effect of subjective norm on perceived behavioral control has the a larger effect $(0.418)$ than attitude (0.413) and purchase intention (0.037). The direct effect of perceived behavioral control toward on purchase intention has a larger influence (0.678) than buying behavior $(-0.277)$. There are also direct effect of attitude on purchase intention (0.544) and the direct effect of purchase intention on purchase behavior (0.984). 
Table 6. Direct effects, indirect effects and total effects

\begin{tabular}{lccc}
\hline & $\begin{array}{c}\text { Standardized } \\
\text { Direct Effects }\end{array}$ & $\begin{array}{c}\text { Standardized } \\
\text { Indirect Effects }\end{array}$ & $\begin{array}{c}\text { Standardized } \\
\text { Total Effects }\end{array}$ \\
\hline Health Consciousness $\rightarrow$ Subjective Norm & .429 & & .429 \\
Health Consciousness $\rightarrow$ Perceived Behavioral Control & .488 & .179 & .668 \\
Health Consciousness $\rightarrow$ Attitude & .437 & .177 & .614 \\
Health Consciousness $\rightarrow$ Purchase Intention & -.231 & .802 & .571 \\
Health Consciousness $\rightarrow$ Purchase Intention & & .377 & .377 \\
Subjective Norm $\rightarrow$ Perceived Behavioral Control & .418 & & .418 \\
Subjective Norm $\rightarrow$ Attitude & .413 & & .413 \\
Subjective Norm $\rightarrow$ Purchase Intention & .037 & .508 & .545 \\
Subjective Norm $\rightarrow$ Purchase Behavior & & .420 & .420 \\
Perceived Behavioral Control $\rightarrow$ Purchase Intention & .678 & & .678 \\
Perceived Behavioral Control $\rightarrow$ Purchase Behavior & -.277 & .666 & .390 \\
Attitude $\rightarrow$ Purchase Intention & .544 & & .544 \\
Attitude $\rightarrow$ Purchase Behavior & & .535 & .535 \\
Purchase Intention $\rightarrow$ Purchase Behavior & .984 & & .984 \\
\hline
\end{tabular}

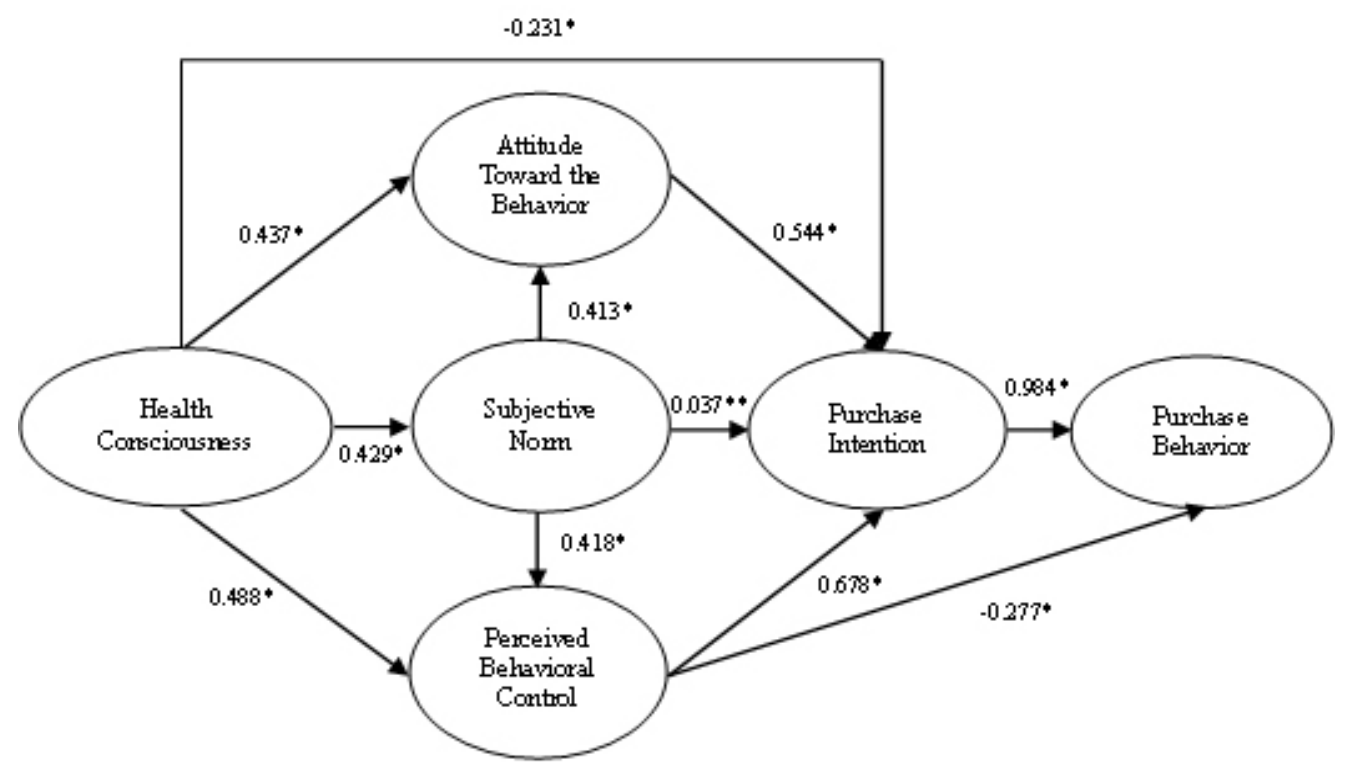

Figure 4. Direct effects (*significant, **not significant)

\section{Managerial Implications}

Organic vegetable producers in the city of Bandung should increase product availability so consumers could buy productses more easily, and producers should also try to understand the behavior of millennial generation consumers better. Manufacturers can implement communication strategies that are appropriate for millennial generation.
Communication could be emphasized through health education and should also be made people aware of the value of organic agriculture and the environment. Communication can be educational by explaining the benefits of organic vegetables compared to nonorganic vegetables (for example, organic vegetables are healthier, safer, free of synthetic chemicals, etc.). Product communication can be done online or offline, considering millennial generation is very active on the internet. The aim is to change consumer behavior from consuming non-organic vegetables to consuming organic vegetables. 


\section{CONCLUSIONS AND RECOMMENDATIONS}

\section{Conclusions}

Based on the results of SEM processed in AMOS, it can be seen that the purchase intention has the most dominant influence on purchase behavior compared to other variables. Whereas, health consciousness as the addition of variables from Theory of Planned Behavior modification has the most effect toward on perceived behavioral control. It is indicated by the path coefficient value of 0.488 .

\section{Recommendations}

Future studies are recommended, using a larger sample and done in more cities rather than Bandung only. Research in Indonesian major cities or even research in national scope would be even better.

\section{REFERENCES}

Ajzen I. 1991. The theory of planned behavior. Organizational Behavior \& Human Decision Processes 50:179-211.

Ajzen I. 2002. Perceived behavioral control, selfefficacy, locus of control, and the theory of planned behavior. Journal of Applied Social Psychology 32: 665-683. Doi: 10.1111/j.15591816.2002. tb00236.x.

Ajzen I. 2005. Attitudes, Personality and Behavior. Second Edition. Open University Press.

Bandura A. 1977. Self-efficacy: Toward a Unifying Theory of Behavioral Change. Psychological Review 84(2): 191-215. Doi: 10.1037/0033295X.84. 2.191

[BPS] Badan Pusat Statistik. 2018. Jumlah Penduduk dan Rasio Jenis Kelamin Menurut Kecamatan di Kota Bandung Tahun 2018. https://www.bps. go.id/. [5 Dec2019].

[BPS] Badan Pusat Statistik. 2018. Kota Bandung Dalam Angka 2019. https://www.bps.go.id/. [24 Feb 2020].

[BPS] Badan Pusat Statistik. 2019. Provinsi Jawa Barat Dalam Angka 2019. https://www.bps.go.id/. [17 Feb 2020].

[BSN] Badan Standarisasi Nasional. 2016. Sistem Pertanian Organik. Standar Nasional Indonesia (SNI) 6729:2016. https://www.bsn.go.id/. [23 Jan 2020].
Chaudhary R. 2018. Green buying behavior in India: an empirical analysis. Journal of Global Responsibility 9(2): 179-192. DOI 10.1108/ JGR-12-2017-0058.

Chaudhary R, Bisai S. 2018. Factors influencing green purchase behavior of millennials in India. Management of Environmental Quality: An Internation Journal 29(5): 798-812. DOI 10.1108/MEQ-02-2018-0023.

De Leeuw A, Valois P, Ajzen I, dan Schmid P. 2015. Using the theory of planned behavior to identify key beliefs underlying pro-environmental behavior in high-school students: implications for educational interventions. Journal of Environmental Psychology 42: 128-138.

Hair JF, Black WC, Babin BJ, Anderson RE. 2010. Multivariate Data Analysis, 7th ed. New Jersey: Pearson Prentice Hall.

Hossain ST, Sugimoto H, Ueno H, Huque SMR. 2007. Adoption of Organic Rice For Sustainable Development in Bangladesh. Journal of Organic Systems 2(2): 27-37.

Hsu SY, Chen CC, Lin TT. 2016. An analysis of purchase intentions toward organic food on health consciousness and food safety with/under structural equation modeling. British Food Journal 188(1): 200-216.

Islam S. 2014. Marketing organic foods through conventional retail outlets. Journal of Marketing Development and Competitiveness Vol. 8(1).

Michaelidou N, Hassan LM. 2008. The role of health consciousness, food safety concern and ethical identity on attitudes and intentions towards organic food. International Journal of Consumer Studies 32: 163-170.

Muljaningsih S. 2011. Preferensi Konsumen dan Produsen Produk Organik Indonesia. Wacana 14(4):1-5.

Oei I. 2010. Riset Sumber Daya Manusia. Jakarta: PT Gramedia Pustaka Utama.

Paul J, Modi A, Patel J. 2016. Predicting green product consumption using theory of planned behavior and reasoned action. Journal of Retailing and Consumer Services 29: 123-134.

Putra YS. 2016. Theoritical Review: Teori Perbedaan Ge nerasi. Among Makarti 9(18).

Rizkia C. 2019. 9 Perilaku Milenial Indonesia, Kecanduan Internet Hingga Dompet Tipis. https://technologue.id. [2020 Mar 3].

Shaharudin MR, Pani JJ, Mansor SW, Elias SJ, Sadek DM. 2010. Purchase intention of organic 
food in kedah, malaysia: a religious overview. International Journal of Marketing Studies 2(1): 96-103.
Worthington. 2001. Nutritional quality of organik versus conventional fruits, vegetables, and grains. International Journal of Complementary and Alternative Medicine 7 (2) :161-173. 